Original article

\title{
The potential of global solar radiation in the Silesia region as a renewable source of energy
}

\section{Katarzyna Waniek}

Faculty of Earth Sciences, University of Silesia, Będzińska Str. 60, 41-200 Sosnowiec, Poland E-mail address: waniek.katarzyna@gmail.com

\begin{abstract}
Historically, Silesia has been at the centre of the Polish coal industry for many years and thus has experienced poorer air quality compared to other voivodeships. However, in recent years strong economic transformation in the area has led to a considerable reduction in coal production. This study aimed to assess the variability of global solar radiation at selected stations within the Silesian voivodeship, in order to re-evaluate the resources of renewable solar energy during the period 1994-2013. The theoretical potential of solar radiation was calculated based on a three-dimensional terrain model. The data on global solar radiation from 13 stations within the Silesia region, covering the period 1994-2013, were obtained from the Regional Inspectorate of Environmental Protection in Katowice. The most favourable conditions for the use of solar energy were found at the cities Sosnowiec and Cieszyn. The largest increase in global radiation over the research period was observed in Zabrze. The average annual global radiation ranged between $600-1300 \mathrm{kWh} \cdot \mathrm{m}^{-2}$. Digital Elevation Models (DEM) for selected districts of the Silesia region were used to calculate the theoretical potential of global solar radiation. The highest theoretical potential of global radiation was found in the district of Cieszyn, located at the highest altitude.
\end{abstract}

KEY WORDS: global solar radiation, renewable energy, DEM, Silesia region

ARTICLE HISTORY: received 21 June 2016; received in revised form 26 August 2016; accepted 26 October 2016

\section{Introduction}

The use of coal as a main energy source in the Silesia region has resulted in a significant increase in the concentration of pollutants (releasing sulphur dioxide, nitrogen oxides, carbon dioxide and various dusts into the atmosphere). The emission of harmful products from fossil fuel combustion can be reduced through the substitution of traditional fuels by energy from renewable sources, which are, in comparison to carbon dioxide, considered to have a neutral impact on the environment (BUJAKOWSKI ET AL., 2005). Currently, the worldwide search for alternative sources of energy is conducted on a large scale. The sun is a practically inexhaustible source of energy. Solar energy is safe, clean and accessible for everyone. This paper aims to document the changes in global solar radiation in the Silesian region in the years 1994-2013 and to assess the potential of regional solar radiation as a renewable energy source. The theoretical potential of global solar radiation using DEM has been calculated for the first time for selected districts of the Silesian voivodeship. A combination of both measured and modelled values of global radiation allowed for a detailed assessment of spatial variability of solar renewable energy resources.

\section{Materials and methods}

This study used average hourly global radiation intensity data from 13 stations (Fig. 1). The data was obtained from the Regional Inspectorate of Environmental Protection in Katowice (Wojewódzki Inspektorat Ochrony Środowiska - WIOŚ). The data covers the period 1994-2004 for the following stations: Bytom, Chorzów, Gliwice, Piekary Śląskie, Sosnowiec, Wojkowice, Zabrze and the period of 2005-2013 for the stations: Dąbrowa Górnicza, Wodzisław Śląski, Rybnik, Cieszyn, Tychy, 
Sosnowiec (Station at the Faculty of Earth Sciences University of Silesia), Zabrze (Fig. 1). Due to transformation of the WIOŚ (automatic monitoring) and resulting changes in the procedures of radiation measurement it was not possible to gather the data for the entire 1994-2013 period. All the available data on global solar radiation from the Silesia region were used in this study.

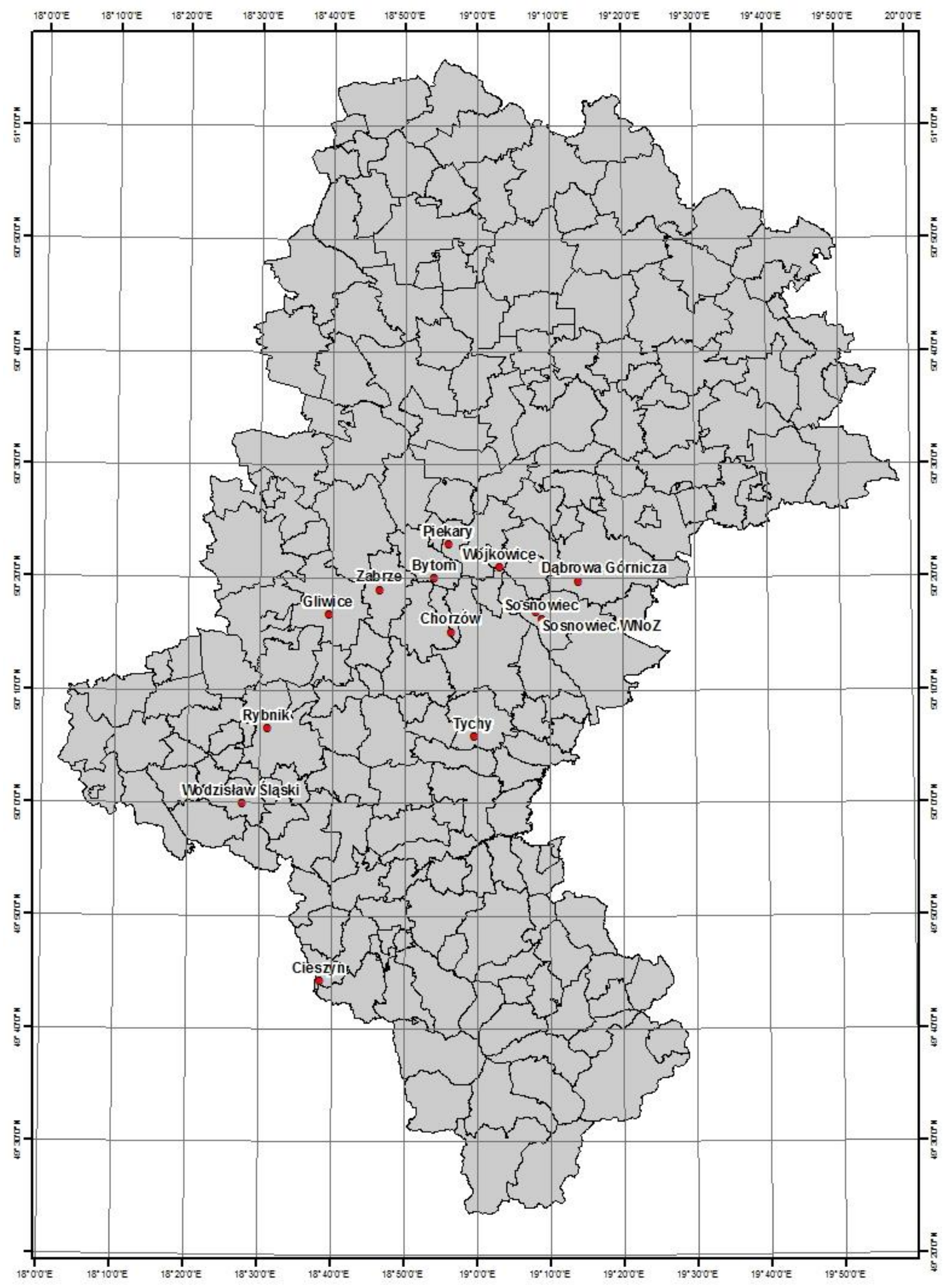

Fig. 1. Location of meteorological stations in the Silesian voivodeship

The data have an hourly time resolution and were expressed in $\mathrm{kW} \cdot \mathrm{m}^{-2}$. Monthly and annual totals of global radiation were then calculated and expressed in $\mathrm{kW} \cdot \mathrm{m}^{-2}$. Using the multi-annual data we conducted an analysis of the global solar radiation. Changes in the global solar radiation from 1994-2004 and from 2005-2013 were calculated and expressed as a percentage of global solar radiation for 2004 and 2013 respectively to determine the changes in solar radiation during the period. The classification of stations with respect to the cost-effectiveness of solar energy use was also performed. The number of hours with total radiation exceeding the $100 \mathrm{~W} \cdot \mathrm{m}^{-2}$ and $300 \mathrm{~W} \cdot \mathrm{m}^{-2}$ threshold values was also calculated for both periods.

Using ArcGIS software the theoretical potential of solar radiation was calculated in selected districts of the Silesian region based on the digital elevation models in the PUWG 1992 coordinate 
system. The Digital Elevation Model that was used was the DTED 2 - model developed by vectorization slides of military topographic maps at a scale of 1:50 000. DEM standard DTED 2 is mainly used in topographic units of the Polish Army. DTED terrain model accuracy depends mainly on the type and accuracy of the source material used for its manufacture. According to a narrow-NATO standardization agreement STANAG 2215 Evaluation of Land Maps, Aeronautical Charts and Digital Topographic Data. Although the models have been developed for ideal conditions, including full transparency of the atmosphere, it should be emphasized that solar radiation is continuously influenced by landform features, altitude, slopes and the presence of water reservoirs. The time interval selected was for the whole year. Calculations were performed for the whole year using monthly intervals. A single output was created for each whole year. The sky size for viewshed was created as a raster of $200 \times 200$ cells. The value of zenit divisions is eight divisions (relative to zenith). The values of azimuth divisions are eight (relative to north). The value of diffuse proportion is 0,3 for generally clear sky conditions. Transmissivity is 0,5 for a general clear sky. The reservoir's water temperature differs from the surroundings. It slowly gains or loses heat. While on land the solar radiation can only be absorbed in the shallow surface layer, in water bodies it can be much deeper. Depending on the chemical composition of the water, the quantity of plankton and the quantities of suspended sediment in the water the solar radiation can be absorbed at different depths in water bodies. Also, the roughness of the water surface of these water bodies is much lower than land. However, cloud cover is also a very important factor influencing the volume of global solar radiation. In clear sky conditions the intensity of global radiation primarily consists of direct radiation, whereas on completely overcast days scattered radiation dominates. Since radiation can be greatly affected by topography and surface features, a key component of the calculation algorithm requires the generation of an upward-looking hemispherical viewshed for every location in the DEM.

\section{Results}

In the period 1994-2004 the highest measurement of global radiation was found in Sosnowiec and Zabrze (over $1313 \mathrm{kWh} \cdot \mathrm{m}^{-2}$ per year in 2003), and the weakest level of radiation was recorded in Bytom $\left(600 \mathrm{kWh} \cdot \mathrm{m}^{-2}\right.$ per year in 2004). Regional variability in global radiation over the Silesia region results from many local factors, as well as spatial variability in air pollution.

The long-term range of global radiation was characterized by a noticeable spatial variability. The station in Bytom saw the biggest drop in global radiation, evidenced by a difference of $-30.1 \%$ between 1994 and 2004 (Tab. 1). The largest increase was recorded in Zabrze (46.6\%) and Sosnowiec (18.9\%). However, the change in Zabrze $(46.6 \%)$ was twice that recorded in Sosnowiec (18.9\%). In the period 1994-2004 the global radiation ranged between $625 \mathrm{kWh} \cdot \mathrm{m}^{-2}$ per year (Bytom) and $1313 \mathrm{kWh} \cdot \mathrm{m}^{-2}$ per year (Zabrze) over the research area (Fig. 2). A slow upward trend in global radiation was found in Zabrze between 1994 and 2001 followed by a clear jump in 2002. The biggest year to year fluctuations were observed in Piekary Śląskie.

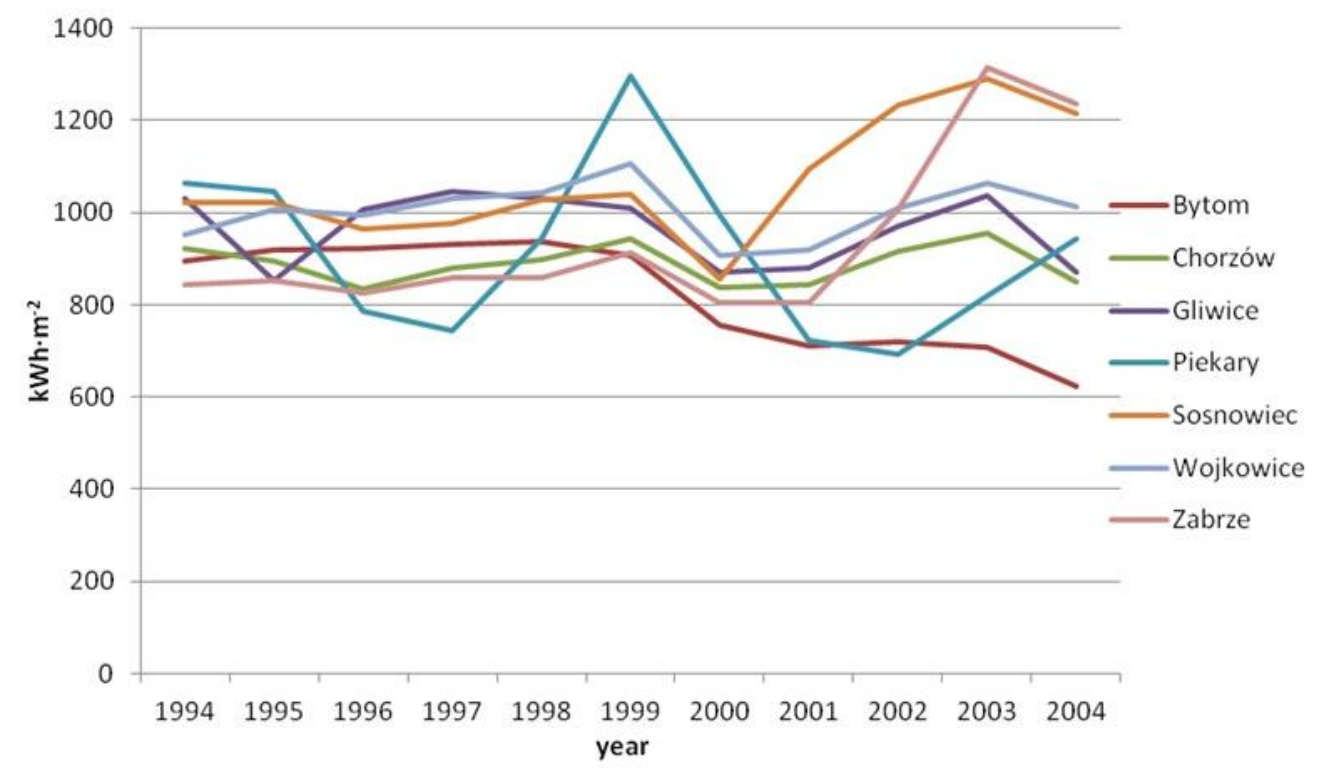

Fig. 2. Range of global solar radiation at selected stations in 1994-2004 [kWh·m-2] 
Table 1. Change in [\%] in global solar radiation between 2004-1994 and between 2013-2005

\begin{tabular}{|c|c|c|c|c|c|c|}
\hline Station & $\varphi$ & $\lambda$ & $\begin{array}{c}\text { Height } \\
\text { m a.s.l. }\end{array}$ & Land use & Period & $\begin{array}{c}\text { Coefficient of } \\
\text { variation }\end{array}$ \\
\hline Zabrze & $50^{\circ} 19^{\prime}$ & $18^{\circ} 46^{\prime}$ & 254 & urban & $1994-2004$ & $+46,6$ \\
\hline Bytom & $50^{\circ} 20^{\prime}$ & $18^{\circ} 53^{\prime}$ & 271 & urban & $1994-2004$ & $-30,1$ \\
\hline Chorzów & $50^{\circ} 15^{\prime}$ & $18^{\circ} 56^{\prime}$ & 283 & communication & $1994-2004$ & $-7,8$ \\
\hline Gliwice & $50^{\circ} 16^{\prime}$ & $18^{\circ} 39^{\prime}$ & 238 & urban & $1994-2004$ & $-15,7$ \\
\hline Piekary & $50^{\circ} 23^{\prime}$ & $18^{\circ} 56^{\prime}$ & 276 & suburban type & $1994-2004$ & $-11,5$ \\
\hline Sosnowiec & $50^{\circ} 16^{\prime}$ & $19^{\circ} 08^{\prime}$ & 254 & urban & $1994-2004$ & $+18,9$ \\
\hline Wojkowice & $50^{\circ} 21^{\prime}$ & $19^{\circ} 03^{\prime}$ & 272 & suburban type & $1994-2004$ & $+6,4$ \\
\hline Zabrze & $50^{\circ} 19^{\prime}$ & $18^{\circ} 46^{\prime}$ & 254 & urban & $2005-2013$ & $-17,7$ \\
\hline Dąbrowa Górnicza & $50^{\circ} 19^{\prime}$ & $19^{\circ} 13^{\prime}$ & 290 & urban & $2005-2013$ & $-12,9$ \\
\hline Wodzisław Śląski & $50^{\circ} 00^{\prime}$ & $18^{\circ} 27^{\prime}$ & 235 & urban & $2005-2013$ & $-24,9$ \\
\hline Rybnik & $50^{\circ} 06^{\prime}$ & $18^{\circ} 30^{\prime}$ & 241 & urban & $2005-2013$ & $-17,9$ \\
\hline Cieszyn & $49^{\circ} 44^{\prime}$ & $18^{\circ} 38^{\prime}$ & 344 & suburban type & $2005-2013$ & $-15,8$ \\
\hline Tychy & $50^{\circ} 06^{\prime}$ & $18^{\circ} 59^{\prime}$ & 248 & urban & $2005-2013$ & $+3,1$ \\
\hline Sosnowiec WnoZ & $50^{\circ} 17^{\prime}$ & $19^{\circ} 08^{\prime}$ & 262 & urban & $2005-2013$ & $-6,1$ \\
\hline \multicolumn{7}{|l|}{} \\
\hline Zabrze & $50^{\circ} 19^{\prime}$ & $18^{\circ} 46^{\prime}$ & 245 & urban & $1994-2013$ & $+0,7$ \\
\hline
\end{tabular}

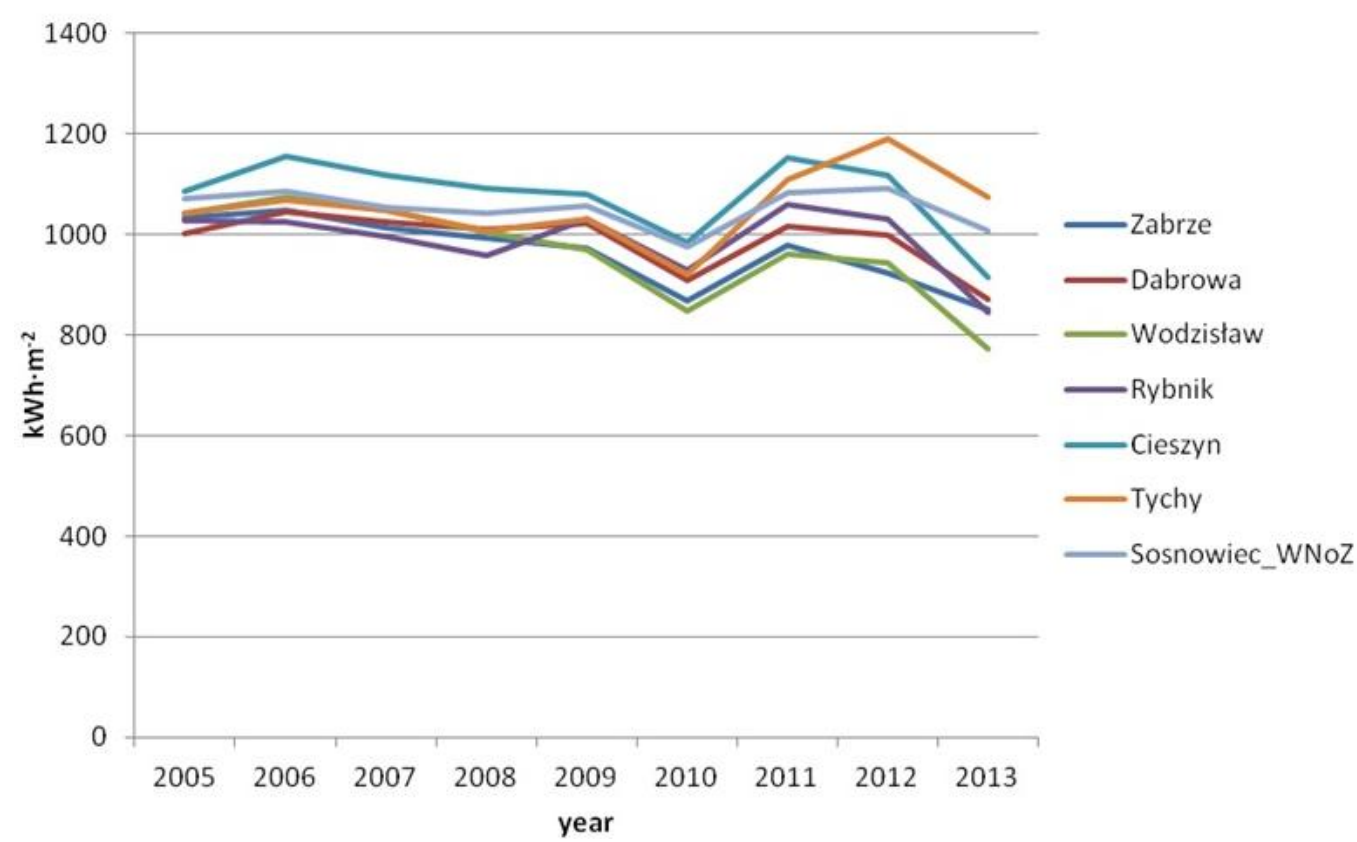

Fig. 3. The long-term range of global solar radiation at selected stations in the period $2005-2013\left[\mathrm{kWh} \cdot \mathrm{m}^{-2}\right.$ per year]

In the second of the research periods (20052013) the highest global radiation was recorded in Tychy and Cieszyn (more than $1100 \mathrm{kWh} \cdot \mathrm{m}^{-2}$ per year) and the lowest in Wodzisław (773 $\mathrm{kWh} \cdot \mathrm{m}^{-2}$ per year) (Fig. 3). The long-term changes in global radiation are less spatially variable in comparison to the previous period of 1994-2004, which is indicated by the similar long-term course. In the period 2005-2013 similar trends were observed at all stations.
The number of hours with global radiation $>100 \mathrm{~W} \cdot \mathrm{m}^{-2}$ and $>300 \mathrm{~W} \cdot \mathrm{m}^{-2}$ were calculated for winter (X-III) and summer (IV-IX). The number of daylight hours in summer is more than 2.5 times that in winter. The number of hours with global radiation exceeding the threshold value of 300 $\mathrm{W} \cdot \mathrm{m}^{-2}$ is more than twofold less than in the case of a threshold of $100 \mathrm{~W} \cdot \mathrm{m}^{-2}$ (Tab. 2).

In the period 2005-2013 the highest number of hours with global radiation $>100 \mathrm{~W} \cdot \mathrm{m}^{-2}$ was 
also observed in Sosnowiec (winter: $784 \mathrm{~h}$, summer: 1927h). The lowest number of hours was observed in Dąbrowa Górnicza (winter: 684 h, summer: 1725 h) (Tab. 3).

Based on the number of hours exceeding the threshold values, classification of the station with regard to the benefits of solar energy use was carried out. The classification was created subjectively using the maximum number of hours in excess of the threshold values.
The cities in the Silesian region were divided into four areas based on the usefulness of solar energy (Table 4). The first area, comprising Sosnowiec and Cieszyn, is the most suitable both for mounting solar installations in larger enterprises as well as in single and multi-family houses. Within the areas classified into the "not beneficial" group the solar energy may only be used for the needs of single-family housing, for heating water or powering small household appliances. For large enterprises could be produce too low energy.

Table 2. Number of hours with global radiation exceeding the $100 \mathrm{~W} \cdot \mathrm{m}^{-2}$ and $300 \mathrm{~W} \cdot \mathrm{m}^{2}$ threshold values in the period $1994-2004$

\begin{tabular}{|c|c|c|c|c|c|c|c|}
\hline \multicolumn{8}{|c|}{ Number of hours } \\
\hline \multicolumn{8}{|c|}{$100 \mathrm{~W} \cdot \mathrm{m}^{-2}$} \\
\hline Season & Bytom & Chorzów & Gliwice & Piekary & Sosnowiec & Wojkowice & Zabrze \\
\hline $\mathrm{X}$-III & 569 & 638 & 681 & 686 & 734 & 730 & 542 \\
\hline IV-IX & 1651 & 1734 & 1778 & 1806 & 1848 & 1830 & 1716 \\
\hline Year & 2220 & 2372 & 2459 & 2492 & 2582 & 2561 & 2257 \\
\hline \multicolumn{8}{|c|}{$300 \mathrm{~W} \cdot \mathrm{m}^{-2}$} \\
\hline $\mathrm{X}$-III & 124 & 160 & 192 & 146 & 233 & 205 & 125 \\
\hline IV-IX & 879 & 973 & 1092 & 934 & 1188 & 1124 & 1067 \\
\hline Year & 1003 & 1133 & 1284 & 1080 & 1422 & 1329 & 1192 \\
\hline
\end{tabular}

Table 3. Number of hours with global radiation exceeding the $100 \mathrm{~W} \cdot \mathrm{m}^{-2}$ and $300 \mathrm{~W} \cdot \mathrm{m}^{-2}$ threshold values in the period 2005-2013

\begin{tabular}{|c|c|c|c|c|c|c|c|}
\hline \multicolumn{8}{|c|}{ Number of hours } \\
\hline \multicolumn{8}{|c|}{$100 \mathrm{~W} \cdot \mathrm{m}^{-2}$} \\
\hline Season & Dabrowa & Wodzisław & Rybnik & Cieszyn & Tychy & $\begin{array}{c}\text { Sosnowiec } \\
\text { WNoZ }\end{array}$ & Zabrze \\
\hline $\mathrm{X}$-III & 684 & 687 & 722 & 767 & 684 & 784 & 686 \\
\hline IV-IX & 1725 & 1768 & 1825 & 1833 & 1817 & 1927 & 1777 \\
\hline Year & 2410 & 2455 & 2547 & 2600 & 2501 & 2712 & 2463 \\
\hline \multicolumn{8}{|c|}{$300 \mathrm{~W} \cdot \mathrm{m}^{-2}$} \\
\hline $\mathrm{X}$-III & 225 & 187 & 190 & 274 & 196 & 233 & 199 \\
\hline IV-IX & 1061 & 1072 & 1112 & 1176 & 1174 & 1208 & 1058 \\
\hline Year & 1286 & 1260 & 1302 & 1450 & 1370 & 1441 & 1257 \\
\hline
\end{tabular}

The theoretical potential of solar radiation was calculated based on DEM and was created in the coordinate system PUWG 1992, taking into account the sun's position, geographical coordinates with a transparent atmosphere and ideal sunlight conditions for the whole year. The results are given in $\mathrm{kWh} \cdot \mathrm{m}^{-2}$ per year. The main components of the numerical model are actually spatial data. They consist of two parts - the first containing the value of the variable (attribute data) and the second specifying the location, or position, in space (data graphic or geometric) (URBAŃSKI, 2008). In the numerical map one pixel corresponds to an area of $30 \times 30 \mathrm{~m}$. The global solar radiation originating from each sky direction is calculated using a sunmap in the same hemispherical projection as the viewshed. A sunmap is a raster representation that displays the sun's track, or apparent position of the sun as it varies through the hours of day and through the days of the year. The sunmap consists of discrete sunmap sectors defined by the sun's position at particular intervals during the day (hours) and time of year (days or months). The sun track is calculated based on the latitude of the study area and the time configuration that defines sunmap sectors. For each sunmap sector, a unique identification value is specified, along with its centroid zenith 
and azimuth angle. The solar radiation originating from each sector is calculated separately, and the viewshed is overlain on the sunmap for calculation of global radiation. The solar radiation analysis tools enable mapping and analysis of the effects of the sun over a geographic area for specific time periods. It accounts for atmospheric effects, site latitude and elevation, steepness (slope) and compass direction (aspect), daily and seasonal shifts of the sun angle, and effects of shadows cast by surrounding topography.

The theoretical potential of solar radiation is dependent on several factors: the landform features, the absolute heights within the area, the tilting of slopes, and the appearance of watercourses. The more varied a landform, the greater the range of values of solar radiation. The most elevated parts of the area are characterized by the highest radiation, which reached 1072$1167 \mathrm{kWh}$ per year in the Cieszyn district with the culmination of Mount Barania reaching 1220 $\mathrm{m}$ a.s.l. (with the River Vistula's source at its foothills). Other peaks include: Czantoria $995 \mathrm{~m}$ a.s.l., Stożek 978 m a.s.l., Równica 885 a.s.l., Błatnia $917 \mathrm{~m}$ a.s.l. (PUKOWSKA-MiTKA \& TKOCZ, 2013). In Cieszyn the amount of the theoretical potential was closest to the measured annual solar radiation, which equals the technical potential. The technical potential of energy is the amount of energy during the year which may be obtained from the resources using the best and most modern processing technology of energy from renewable sources taking into account the spatial and environmental constraints. In contrast, in urban stations the theoretical potential is significantly different from the technical potential, which may result from a higher pollution concentration than in the suburban Cieszyn station. Within those districts typified by a varied topography a clear difference in the level of global radiation was found. The northern exposures were characterised by a reduced amount of global radiation, but much higher global radiation totals were recorded on the southern exposures. Station measurements deliver only solar radiation data for sparse point-locations. However, detailed information on the theoretical potential of global solar radiation can be obtained from digital landform modelling. A combination of both measured and modelled values of global solar radiation allows for a better assessment of solar radiation as a potential renewable source of energy within the research area.

Table 4. Classification of stations with respect to the benefit of solar energy use

\begin{tabular}{|c|c|c|}
\hline Area & Station & Reionization \\
\hline I & Sosnowiec WNoZ² & more beneficial \\
\hline II & Cieszyn $^{2}$ & more beneficial \\
\hline III & Sosnowiec ${ }^{1}$ & morebeneficial \\
\hline IV & Wojkowice ${ }^{1}$ & beneficial \\
\hline V & Tychy² & beneficial \\
\hline VI & Rybnik $^{2}$ & beneficial \\
\hline VII & Gliwice ${ }^{1}$ & medium beneficial \\
\hline VIII & Wodzisław ${ }^{2}$ & medium beneficial \\
\hline IX & Zabrze $^{1,2}$ & medium beneficial \\
\hline $\mathrm{X}$ & Dąbrowa $^{2}$ & not beneficial \\
\hline XI & Piekary ${ }^{1}$ & not beneficial \\
\hline XII & Chorzów ${ }^{1}$ & not beneficial \\
\hline XIII & Bytom ${ }^{1}$ & not beneficial \\
\hline
\end{tabular}




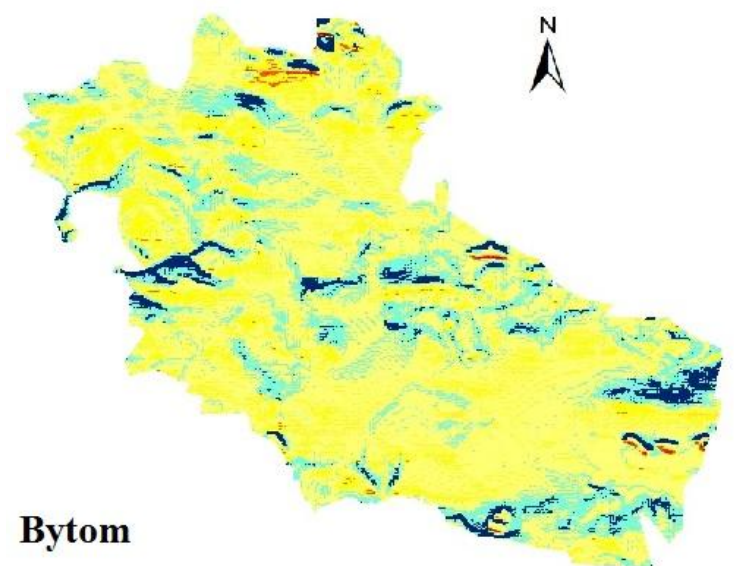

$900 \quad 1000,3000$ Meters

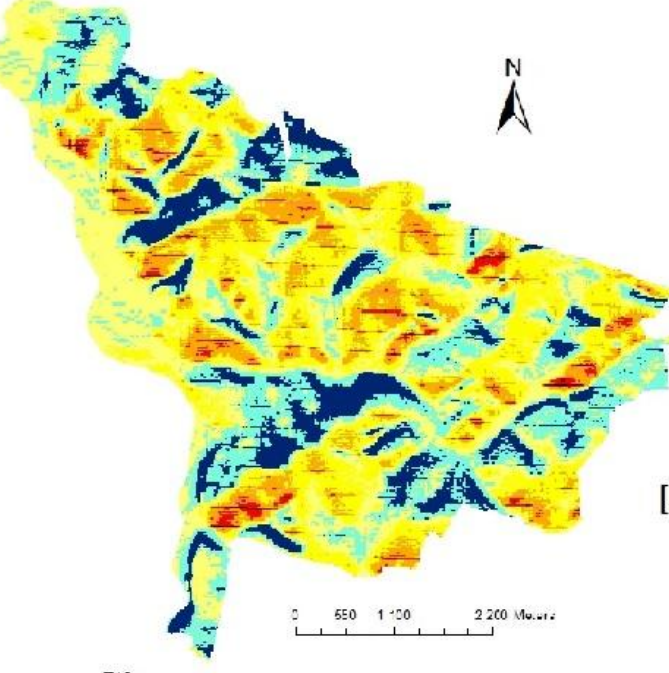

\section{Cieszyn}

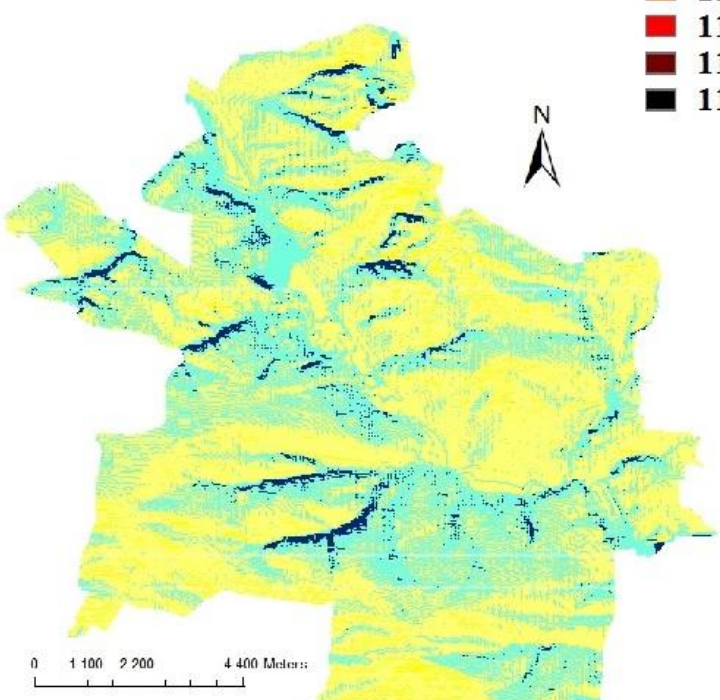

Gliwice

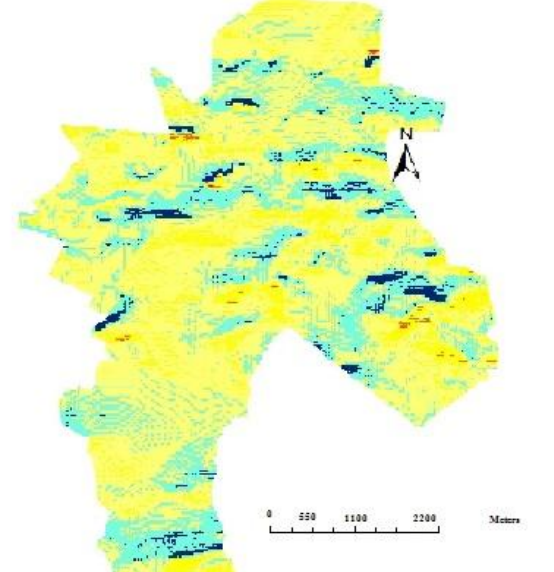

Chorzów

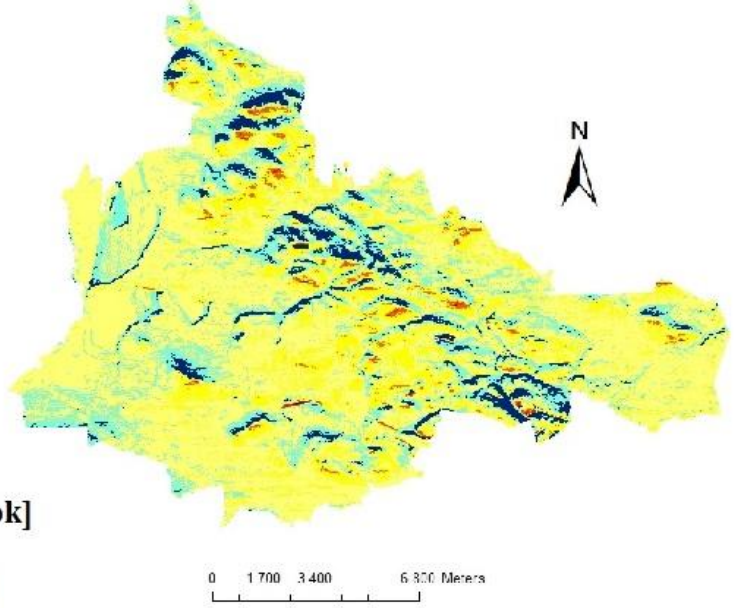

Dąbrowa Górnicza

$\left[\mathrm{kWh} / \mathrm{m}^{2} / \mathrm{rok}\right]$

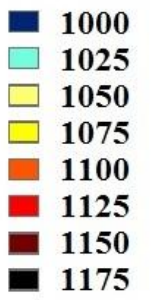

Piekary

Śląskie

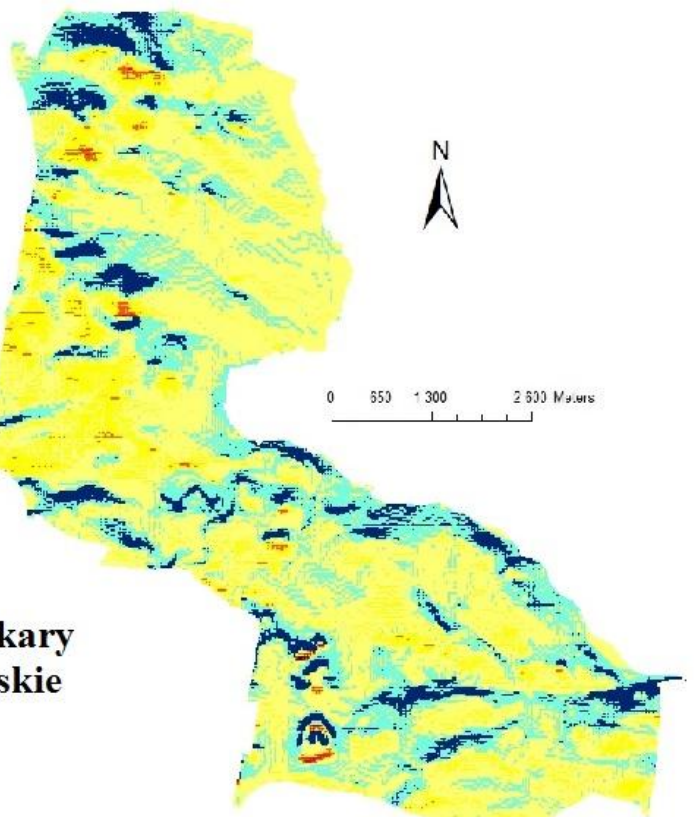

Fig. 4. Theoretical potential of global solar radiation $\left(\mathrm{kWh} \cdot \mathrm{m}^{-2}\right)$ in selected districts in the Silesia region 

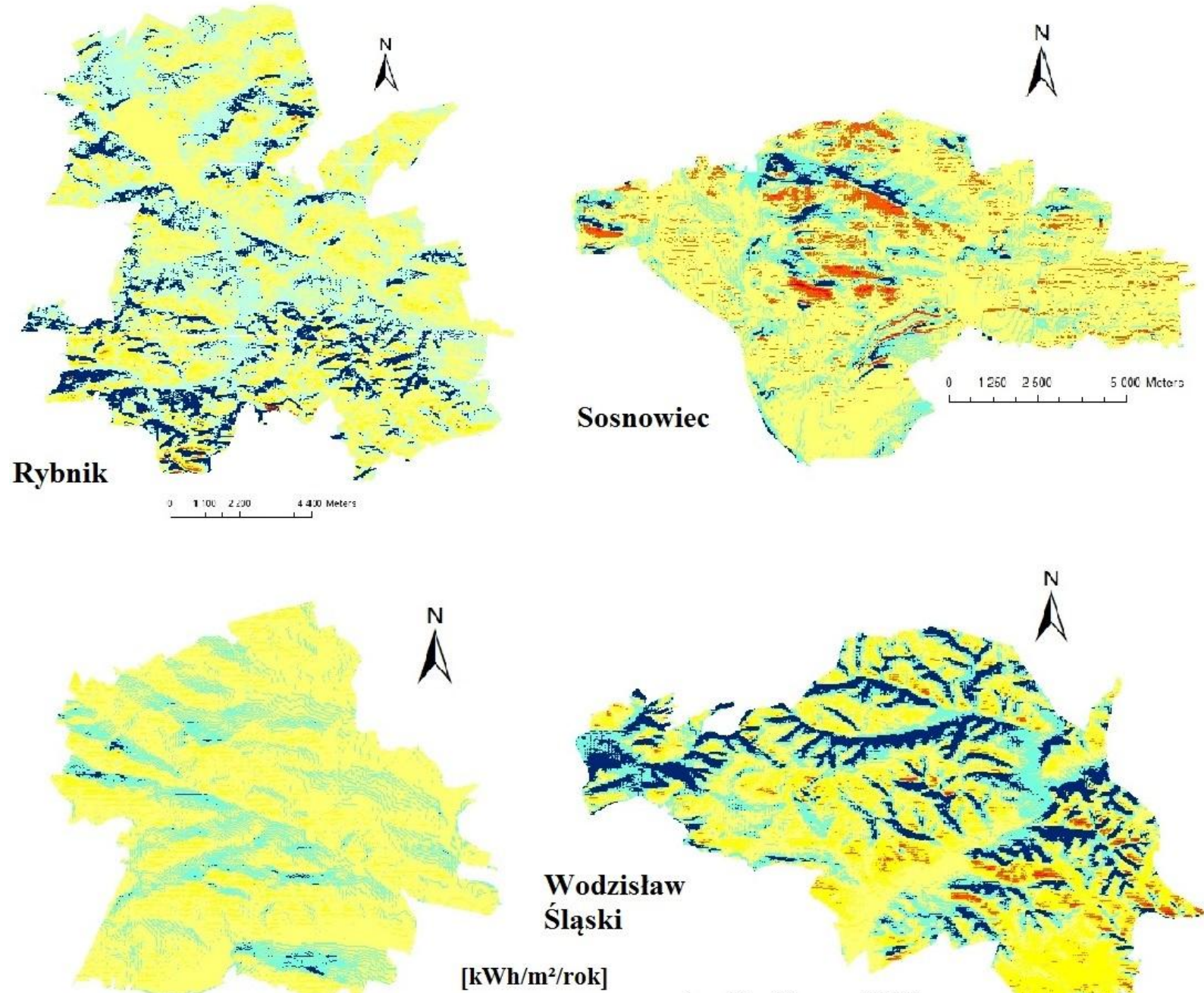

$\stackrel{N}{N}$

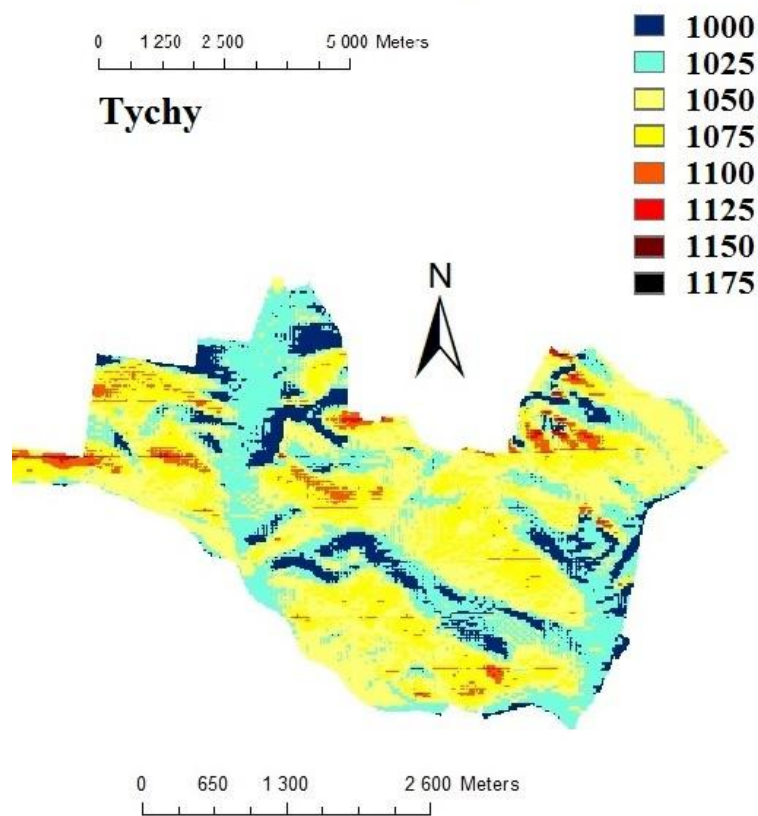

$\left[\mathrm{kWh} / \mathrm{m}^{2} / \mathrm{rok}\right]$

Wojkowice
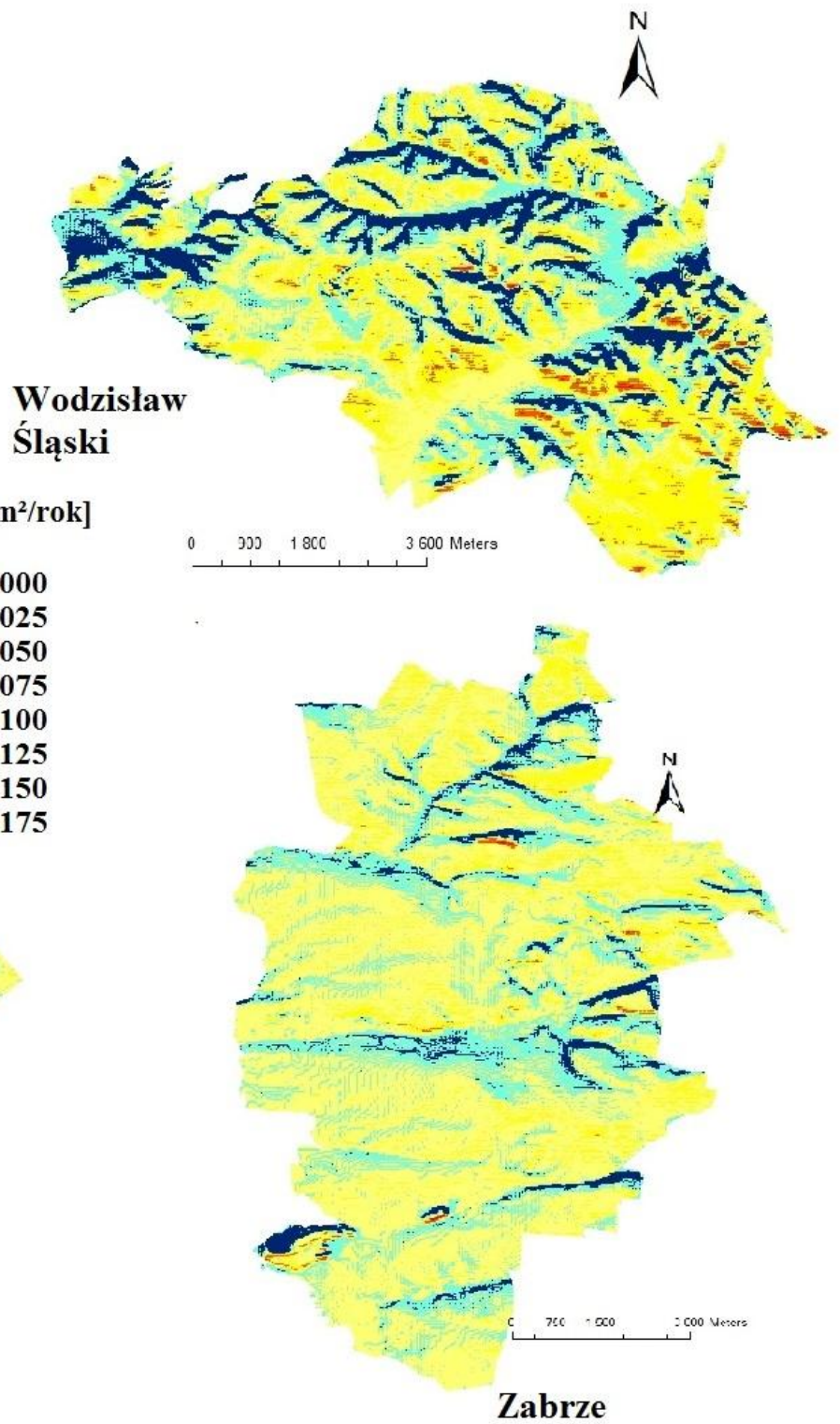

Fig. 5. Theoretical potential of global solar radiation $\left(\mathrm{kWh} \cdot \mathrm{m}^{-2}\right)$ in selected districts in the Silesia region (cont.) 


\section{Discussion and conclusions}

Global solar radiation depends strongly on the specific nature of the landform, the cloud cover and cloud type, and the transparency of the atmosphere. It also depends on the water vapour content in the atmosphere and aerosol concentration.

In the period 1994-2004 the multi-annual course of radiation ranged across the research area from $625 \mathrm{kWh} \cdot \mathrm{m}^{-2}$ per year (Bytom) to $1313 \mathrm{kWh} \cdot \mathrm{m}^{-2}$ per year (Zabrze). In the period 2005- 2013 the highest global solar radiation occurred in Tychy and Cieszyn (more than $1100 \mathrm{kWh} \cdot \mathrm{m}^{-2}$ per year) and the lowest in Wodzisław $\left(773 \mathrm{kWh} \cdot \mathrm{m}^{-2}\right.$ per year). The largest increase in global radiation was observed in Zabrze, where the average annual values of global radiation ranged between 625$1313 \mathrm{kWh} \cdot \mathrm{m}^{-2}$ per year). Similar values were recorded in Ojców National Park by WoJKOWSKI \& CAPUTA (2009), where the annual solar radiation totals ranged from $327 \mathrm{kWh} \cdot \mathrm{m}^{-2}$ per year to 1208 $\mathrm{kWh} \cdot \mathrm{m}^{-2}$ per year and the value of the annual average was $1034 \mathrm{kWh} \cdot \mathrm{m}^{-2}$. The average global radiation for Poland amounts to $1000 \mathrm{kWh} \cdot \mathrm{m}^{-2}$ per year (GoGóŁ, 1993). The long-term range of global radiation in the period 1994-2013 differed depending on the station.

Using the three-dimensional landform models for the regions we calculated the theoretical potential of solar radiation for the Silesian region. Although the models have been developed for ideal conditions, including full transparency of the atmosphere, it should be emphasized that solar radiation is continuously influenced by landform features, altitude, slopes and the presence of water reservoirs. Measured global solar radiation (technical potential) is proportionately lower compared to the theoretical potential of the radiation due to air pollution, cloud cover and other local factors.

\section{References}

Bujakowski W., Barbacki A., Grzybek A., Hołojuch G., Pająk L., Skoczek A., Skrzypczak M., Skrzypczak S. 2005. Opracowanie metody programowania $i$ modelowania systemów wykorzystania odnawialnych źródeł energii na terenach nieprzemysłowych województwa śląskiego, wraz z programem wykonawczym dla wybranych obszarów województwa. Część II: Program wykorzystania odnawialnych źródeł energii na terenach nieprzemysłowych województwa śląskiego (projekt). Inst. Gosp. Sur. Min. i Energii PAN, KrakówKatowice.

Gogół W. (ed.) 1993. Konwersja termiczna energii promieniowania słonecznego w warunkach krajowych. Polska Akad. Nauk, Warszawa.

Pukowska-Mitka M., Tkocz M. 2013. Turystyka w powiecie cieszyńskim. Acta Geogr. Silesiana, 13: 61-69.

Urbański J. 2008. GIS $w$ badaniach przyrodniczych. Wyd. Uniw. Gdańskiego, Gdańsk.

Wojkowski J., Caputa Z. 2009. Modelowanie dopływu promieniowania słonecznego na obszarze Ojcowskiego Parku Narodowego. Prądnik. Prace Muz. Szafera, 19: 141-152. 